\title{
Gender Identity Disorder Pada Tokoh Yuuta Aoki Dalam Komik Bokura No Hentai Karya Fumi Fumiko
}

\author{
Ni Komang Ayu Ariska Dwi Cahyani ${ }^{1 *}$ Ngurah Indra Pradhana ${ }^{2}$, Silvia \\ Damayanti $^{3}$ \\ ${ }^{[123]}$ Program Studi Sastra Jepang Fakultas Ilmu Budaya \\ ${ }^{1}$ [ariskacahyani14@gmail.com] ${ }^{2}$ [indra_pradhana@unud.ac.id] \\ 3 [silvia_damayanti@unud.ac.id] \\ *Corresponding Author
}

\begin{abstract}
The title of this research is "Gender Identity disorder at character Yuuta Aoki in manga Bokura no Hentai by Fumi Fumiko". The aims of this research are to described GID characteristic, the reasons of GID in character yuuta, and any efforts the character do to deal with his own GID in manga Bokura no Hentai by Fumi Fumiko. The theories that have been used are Wellek and Warren's literature and psychology theory (2016), Sigmund Freud'spsychoanalytic theory (2016), First's gender identity disorder theory (1994), and Marcel Danesi's semiotic theory (2011). From the results, it is showed that character Yuuta Aoki is a boy which want to be a girl since he was 4 years old driven by his GID condition. GID characteristic in Yuuta was identified in 3 dimensions 1). Physiology, which is dress himself as a girl and use cosmetics; 2). Psychology, which is declaring himself as a girl, fall in love with boy, irritated to have a male body, imagining himself as girl, and act like a girl; 3). Sociology, which is often got bullied by his friends and usually hanging out with his female friends. The reasons behind Yuuta's GID condition were driven by mimicking and his mother let him to dress himself as a girl. His efforts to deal with his GID were by trying to act like a boy again and consulting with doctor.
\end{abstract}

Keywords: psychology literature, Gender Identity Disorder, Psychoanalytic

Abstrak

Penelitian ini berjudul "Gender Identity Disorder Pada Tokoh Yuuta Aoki Dalam Komik Bokura No Hentai Karya Fumi Fumiko”. Tujuan penelitian ini adalah untuk mendeskripsikan karakteristikGender Identity Disorder(GID), faktor penyebab yang membentuk GID pada tokoh Yuuta, serta upaya tokoh Yuuta mengatasi GID dalam komik Bokura no Hentai karya Fumi Fumiko.Teori yang digunakan adalah teori psikologi sastra Wellek dan Warren (2016), teori psikoanalisis Sigmund Freud (2016), teori Gender Identity Disorder First,dkk (1994), dan teori semiotika Marcel Danesi (2011).Berdasarkan hasil penelitian, tokoh YuutaAoki adalah seorang anak laki-laki akan tetapi ia memiliki keinginan untuk menjadi perempuan sejak berumur 4 tahun akibat GID yang dideritanya. Karakteristik GID pada tokoh Yuuta dibagi berdasarkan tiga dimensi yaitu 1). Dimensi fisiologis antara lain: memakai pakaian perempuan dan memakai kosmetik; 2). Dimensi psikologis antara lain: menyatakan diri perempuan, menyukai laki-laki, tidak merasa nyaman memiliki tubuh laki-laki, berkhayal menjadi perempuan, dan bertingkah laku seperti perempuan; 3) Dimensi sosiologis antara lain: sering mendapatkan ejekan dari teman-temannya dan lebih banyak menghabiskan waktu dengan teman-teman perempuannya. Faktor penyebab terbentuknya GID pada Yuuta disebabkan olehadanya perilaku meniru dan ibu Yuuta yang kerap membiarkan Yuuta memakai pakaian perempuan. Upaya tokoh Yuuta mengatasi GID, yaitu berupaya untuk mencari identitas diri dan berupaya untuk berkonsultasi dengan dokter.

Kata kunci: Psikologi Sastra, Psikoanalisis, Gender Identity Disorder 


\section{(1) Latar Belakang}

Laki-laki maupun perempuan, dewasa ini tidak jarang mempunyai hasrat untuk memiliki jenis kelamin yang berlawanan dengan jenis kelamin yang dimilikinya. Hal tersebut dikarenakan adanya perasaan tidak nyaman atau tidak cocok dengan peran gender yang dimilikinya, dalam dunia medis dikenal dengan Gender Identity Disorder atau GID (First, dkk, 1994:533). GID banyak digambarkan melalui tokoh-tokoh dalam karya sastra, salah satunya karya sastra jepang dalam bentuk komik yang ditulis oleh Fumi Fumiko berjudul Bokura no Hentai yang di dalamnya menggambarkan karakterististik, faktor penyebab, serta upaya tokoh Yuuta Aoki dalam mengatasi GID.

Penelitian ini menggunakan penelitian dari Asih (2016) yang berjudul "Transgender dalam Film Animasi Tokyo Godfather Karya Satoshi Kon" sebagai acuan. Penelitian Asih memberikan gambaran mengenai transgender dan cara pengaplikasian teori semiotika dalam menganalisis data berupa gambar.

\section{(2) Pokok Permasalahan}

Rumusan masalah dalam penelitian ini adalah sebagai berikut:

a. Bagaimanakah karakteristik GID pada tokoh Yuuta Aoki dalam komik Bokura no Hentai karya Fumi Fumiko?

b. Bagaimanakah faktor penyebab dan upaya tokoh Yuuta Aoki untuk mengatasi GID dalam komik Bokura no Hentai karya Fumi Fumiko?

\section{(3) Tujuan penelitian}

Tujuan yang ingin dicapai dalam menganalisis komik Bokura no Hentai karya Fumi Fumiko adalah untuk mengetahui karakteristik GID, faktor penyebab GID, serta upaya tokoh dalam mengatasi GID yang digambarkan melalui perilaku tokoh Yuuta Aoki.

\section{(4) Metode Penelitian}

Penelitian ini dilakukan secara kualitatif dengan metode deskriptif analisis (Ratna, 2011:53). Teori yang digunakan adalah psikologi sastra yang dikemukakan oleh Wellek dan Warren (2016) sebagai payung utama penelitian. Teori psikoanalisis yang dikemukakan oleh Sigmund Freud (2016) untuk menganalisis karakteristik GID pada tokoh Yuuta. Teori gender identity disorder yang dikemukakan oleh First, dkk (1994) untuk menganalisis karakteristik, faktor penyebab, serta upaya tokoh mengatasi GID, serta didukung oleh teori semiotika yang dikemukan oleh Marcel Danesi (2011) untuk menganalisis gambar pada komik.

\section{(5) Hasil dan Pembahasan}

\subsection{Karakteristik GID Pada Tokoh Yuuta Aoki}

Dalam komik Bokura no Hentai, karakteristik GID pada tokoh Yuuta dapat dilihat berdasarkan tiga dimensi, yaitu dimensi fisiologis, dimensi psikologis dan dimensi sosiologis.

\subsubsection{Dimensi Fisiologis}

Dimensi fisiologis adalah penggambaran karakter tokoh dilihat dari ciri fisik karakter tokoh. Karakteristik GID pada tokoh Yuuta berdasarkan dimensi fisiologis yaitu tokoh Yuuta sering memakai pakaian perempuan dan berdandan seperti perempuan. Berikut merupakan salah satu data mengenai karakteristik GID berdasarkan dimensi fisiologis. 


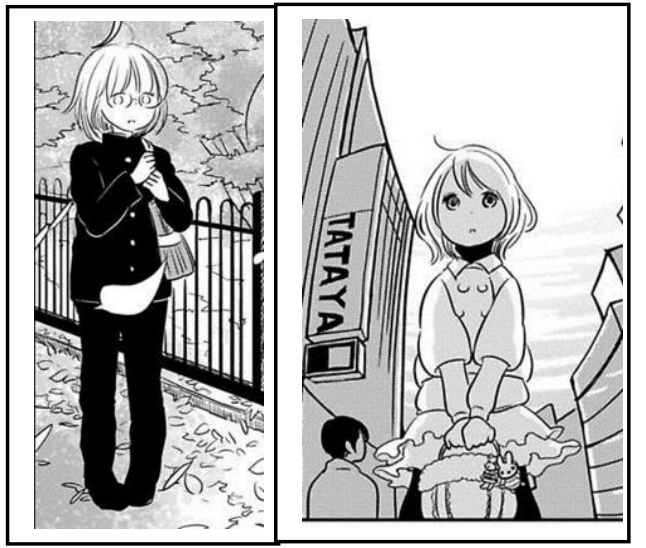

Gambar 1. Tokoh Yuuta saat memakai pakaian laki-laki (kiri) dan tokoh Yuuta saat memakai pakaian perempuan (kanan)

(Bokura no Hentai 3, 2012:3 dan chapter 1, 2012:17)

Gambar (1) merupakan gambar yang menunjukkan tokoh Yuuta saat memakai seragam gakuran (kiri) dan tokoh Yuuta saat memakai pakaian perempuan (kanan). Dalam komik Bokura no Hentai, dapat diketahuii bahwa tokoh Yuuta Aoki adalah seorang remaja laki-laki berusia 12 tahun yang memiliki kebiasaan untuk memakai pakaian perempuan, seperti rok atau dress. Kebiasaan Yuuta memakai pakaian perempuan dimulai sejak ia berusia empat tahun, ia sering kali merengek kepada ibunya untuk dipakaikan pakaian perempuan, bahkan Yuuta pernah menolak untuk pergi ke sekolah jika tidak dipakaikan pakaian perempuan. Oleh karena itu, ibu Yuuta pun mengijinkan Yuuta untuk memakai pakaian perempuan dan kebiasaan itu akhirnya berlangsung hingga Yuuta berusia 12 tahun.

Penderita GID percaya jika mereka adalah perempuan, sehingga mereka menganggap jika sudah sewajarnya seorang perempuan memakai pakaian perempuan (First, dkk, 1994:533). Selain memakai pakaian perempuan, Yuuta juga menyukai berdandan memakai kosmetik seperti pelembab wajah, bedak, mascara, dan lipstick, seperti data berikut.

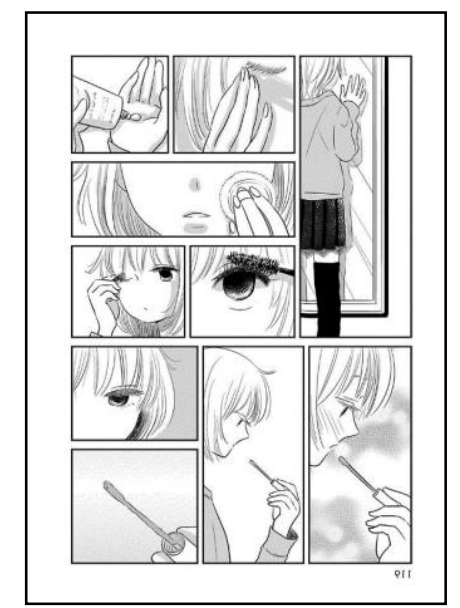

\section{Gambar 2.Tokoh Yuuta sedang memakai kosmetik}

(Bokura no Hentai 2, 2012:119)

Gambar (2) menunjukkan Yuuta sedang memakai kosmetik pemberian Osamu Tamura. Tokoh Yuuta menganggap memakai kosmetik dapat membuatnya semakin terlihat cantik seperti layaknya perempuan sesungguhnya, sehingga ia pun memutuskan memakai kosmetik setiap ia memakai pakaian perempuan. Tindakan Yuuta tersebut sesuai dengan teori gender identity disorder yang dikemukakan oleh First yang menyatakan bahwa penderita GID lebih merasa bahagia dan nyaman saat memakai pakaian atau melakukan kegiatan yang biasanya dilakukan oleh perempuan dan tanpa malu menunjukkan sisi feminim mereka (First, dkk, 1994:534).

\subsubsection{Dimensi Psikologi}

Dimensi psikologis adalah penggambaran karakter tokoh berdasarkan ambisi, tingkah laku dan ciri psikologi lainnya yang mewakili karakter tokoh. Dalam komik Bokura no Hentai, karakteristik GID tokoh Yuuta berdasarkan dimensi psikologi yaitu secara psikologis tokoh Yuuta berambisi untuk menjadi 
perempuan, merasa bahwa dirinya adalah perempuan, menyukai sesama laki-laki, tidak menyukai anatomi tubuh sendiri, selalu berkhayal menjadi perempuan dan bertingkah laku seperti perempuan. Berikut merupakan salah satu data mengenai karakteristik GID tokoh Yuuta Aoki berdasarkan dimensi psikologis.

（1）裕太 ：物心ついたときには

\section{自分は女だと思って}

いた。股についている

異物はいずれなくなる

と胸はいずれ大きくな

る信じてやまなかつた

自然とそうならないと

知った時のショック大

きかったけど...

(ぼくらのへんたい1, 2012:27)

Yuuta : Busshin tsuita toki ni wa jibun wa onna da to omotteita. Mata ni tsuiteiiru ibutsu wa izure naku naru to mune wa izure ookiku naru shinjite yamanakatta shizen to sou nara nai to shita toki no shokku ookikatta kedo...

(Bokura no Hentai 1, 2012: 27)

Terjemahan:

Yuuta : Selama yang ku ingat, aku berpikir bahwa diriku adalah perempuan. aku selalu percaya jika benda asing yang berada diantara kakiku perlahanlahan akan menghilang dan aku juga percaya bahwa dadaku perlahanlahan akan membesar. Aku terkejut mengetahui bahwa itu tidak akan pernah terjadi.

Data (1) menunjukkan tokoh Yuuta mempercayai bahwa dirinya adalah seorang perempuan. Sejak kecil Yuuta selalu percaya bahwa dirinya akan tumbuh menjadi wanita dewasa sehingga ia selalu percaya bahwa suatu saat nanti dadanya akan tumbuh membesar dan penisnya perlahan-lahan akan menghilang dan digantikan dengan vagina. Namun, mengetahui hal tersebut mustahil untuk terjadi menyebabkan Yuuta begitu membenci tubuhnya sendiri, bahkan ia merasa jijik ketika harus menyentuh alat kelaminnya sendiri karena ia merasa ketika ia menyentuh alat kelaminnya akan mengingatkannya kembali akan fakta dirinya bukanlah seorang perempuan. Seorang laki-laki yang menderita GID mengekspresikan penolakan terhadap jenis kelaminnya sendiri kedalam beberapa perilaku, seperti menyukai memakai pakaian perempuan, menolak untuh menyentuh kelamin sendiri, menolak untuk melakukan onani dan berperilaku feminim (First, dkk, 1994:534). Selain itu, anggapan bahwa dirinya adalah seorang perempuan membuat Yuuta memiliki ketertarikan seksual terhadap sesama laki-laki, seperti data berikut.

(2) 舞

: こんなこと聞くのは

失礼だと思うんです

けよ゙、その場合恋愛

対象は女性なん

$$
\text { でしようか }
$$

裕太 ：僕は男の人が

好きみたい 
舞

$$
\begin{gathered}
\text { : そうですか } \\
\text { (ぼくらのへんたい4, 2012:114) }
\end{gathered}
$$

Mai : Konna koto kiku no wa shitsurei dato omoun desu kedo, sono baai renai taishou wa josei nan deshou ka

Yuuta : Boku wa otoko no hito ga suki mitai

Mai : Soudesu ka

(Bokura no Hentai 4, 2012: 114)

Terjemahan:

Mai : Aku pikir sedikit tidak sopan untuk menanyakan hal ini, tetapi pada situasi ini, apakah kamu mau memiliki ketertarikan untuk menjalin hubungan dengan perempuan?

Yuuta : Sepertinya aku lebih menyukai laki-laki....

Mai : Begitu ya

Data (2) menunjukkan tokoh Yuuta yang memiliki ketertarikan seksual terhadap sesama laki-laki yang ditunjukkan pada kalimat "Boku wa otoko no hito ga suki mitai" yang berarti "Sepertinya aku lebih menyukai lakilaki”. Pada tahap perkembangan seksual, penderita GID secara psikologis cenderung lebih tertarik kepada laki-laki dibandingkan perempuan. Hal tersebut disebabkan karena alam bawah sadar mereka atau id percaya jika mereka adalah perempuan sehingga bagi penderita GID menjalin hubungan dengan sesama laki-laki merupakan hal yang wajar layaknya menjalin hubungan heteroseksual (Freud, 2016:157). Tokoh Yuuta selalu percaya bahwa suatu saat nanti ia akan menikah dengan laki-laki yang ditakdirkan untuknya dan bahagia untuk selamanya seperti cerita dongeng yang sering ia baca sejak kecil.

\subsubsection{Dimensi Sosiologis}

Dimensi sosiologis adalah penggambaran karakter tokoh berdasarkan kehidupan sosial tokoh dan interaksi tokoh dengan tokoh lainnya dalam cerita. Sebagai penderita GID Yuuta mengalami kesulitan ketika berinteraksi dengan teman-temannya, ia sering mendapatkan ejekan dari teman-temannya karena perilakunya yang cenderung feminim seperti perempuan, bahkan teman-teman Yuuta secara terangterangan menolak untuk bermain dengan Yuuta seperti data berikut.

（3）友達 1 : 来るなよオカマが

$$
\text { うつつる! }
$$

友達 2 : 裕太が触つちやつた

$$
\text { 友達 } 3: \text { バリーヤ! }
$$

赤ね：コーラ！裕太をいじ

$$
\text { めるな ! }
$$

（ぼくらのへんたい 1、2012:125）

Tomodachi 1 : Kurun nayo okama ga utsuru!

Tomodachi 2 : Yuuta ga sawacchatta!

Tomodachi 3 : Baariya!

Akane

: Koora! Yuuta o ijimeruna!

(Bokura no Hentai 1, 2012:125)

Terjemahan:

Teman Yuuta 1: Jangan mendekat, banci mu menular!

Teman Yuuta 2: Aku menyentuh Yuuta!

Teman Yuuta 3: Pelindung!

Akane : Hei Kalian! Jangan menyakiti Yuuta!

Data (3) merupakan data yang diperoleh saat Yuuta masih menempuh pendidikan di sekolah dasar. Karena kebiasaan Yuuta yang mengenakan 
pakaian perempuan ke sekolah membuatnya sering mendapat ejekan dari teman-temannya yang memandang perilakunya tersebut aneh. Teman-teman Yuuta sering menyebutnya banci karena perilakunya tersebut, bahkan ketika pelajaran renang beberapa teman-teman Yuuta sering melorotkan celananya dan menyembunyikannya. Oleh karena itu, Yuuta enggan berinteraksi atau bermain dengan teman laki-laki sekelasnya sehingga ia lebih banyak menghabiskan waktu dengan Akane dan teman-teman perempuannya. Bahkan ketika SMP, Yuuta lebih memilih mengikuti klub memasak dibandingkan klub yang biasanya menjadi kesukaan siswa lakilaki seperti sepak bola, atau kasti. Hal tersebut dikarenakan anak laki-laki yang menderita GID cenderung tidak menyukai kegiatan atau permainan yang melibatkan fisik seperti sepak bola atau kasti (First, dkk, 1994:533).

\subsection{Faktor Penyebab GID pada Tokoh Yuuta Aoki}

Penyebab utama perilaku GID pada tokoh Yuuta disebabkan oleh faktor lingkungan keluarga tempat Yuuta dibesarkan yaitu adanya perilaku meniru tingkah laku ibunya dan pembiaran perilaku cross-dress.

Berawal dari keputusan perusahaan tempat ayah Yuuta bekerja yang mengharuskan ayah Yuuta untuk dipindahkan bekerja mengurus cabang perusahaan yang berada di Osaka. Hal tersebut menye-babkan Yuuta sangat jarang berinteraksi dengan ayahnya. Tidak adanya figur seorang ayah dalam keluarga menye-babkan Yuuta memandang sosok ibunya sebagai figur pengganti ayahnya, sehingga Yuuta pun mulai meniru semua perilaku ibunya, baik dari cara berbicara maupun cara berpakaian ibunya, seperti data berikut.

（4）裕太 : ねえ わたしあつ

\author{
ちがいい、 \\ 裕太のママ : スカートは女の子 \\ がはくものよ。そ \\ れに私じやなくて、 \\ 僕でしょう \\ 裕太 ：でもお母さんはわ \\ たしっていう \\ でしよう
}

裕太のママ : お母さんは女、

裕ちやんは男

でしよう。

裕太 : わたしも女だもん

(ぼくらのへんたい 3, 2012: 30)

Yuuta : Nee, watashi achhi ga ii

Yuuta no Mama: Sukaato wa onna no ko ga haku mono yo. Sore ni watashi janakute, boku deshou.

Yuuta : Demo okaasan wa watashi tte iu deshou.

Yuuta no mama: Okaasan wa onna, Yuuchan wa otoko deshou

Yuuta : Watashi mo onna damon

(Bokura no Hentai 3, 2012:30)

Terjemahan:

Yuuta : Hei, aku ingin itu

Ibu Yuuta : Rok hanya dipakai oleh perempuan, dan kamu seharusnya mengatakan

'Boku' bukan 'watashi' 


$\begin{array}{ll}\text { Yuuta } & : \text { Tapi Ibu mengatakan } \\ \text { Ibu Yuuta } & \text { 'watashi' } \\ & \text { Itu karena ibu adalah } \\ & \text { perempuan, dan Yuuta } \\ & \text { adalah Laki-laki. }\end{array}$

Yuuta

Data (4) merupakan data yang diperoleh ketika Yuuta masih berumur kira-kira empat tahun. Pada percakapan pada data (4) terlihat tokoh Yuuta meniru cara ibunya berbicara. Ia mengikuti ibunya menggunakan kata "watashi" dari pada menggunakan "boku" untuk menyebut diri sendiri. Ketika ibu Yuuta mencoba mem-benarkan kata-kata Yuuta dengan meng-atakan "Sore ni watashi janakute, boku deshou" yang berarti "kamu seharusnya mengatakan 'boku' bukan 'watashi' akan tetapi Yuuta membela diri dengan mengatakan" Demo okaasan wa watashi tte iu deshou" yang berarti "tapi ibu mengatakan 'watashi'.

Dalam hal ini terlihat jelas jika tokoh Yuuta men-jadikan ibunya sebagai role-figure yang terlihat pada akhir percakapan yang mana Yuuta memandang dirinya sebagai perempuan. Hal tersebut dikarenakan tokoh Yuuta hanya menghabiskan waktu selama bertahun-tahun hanya bersama ibunya sehingga ia gagal meng-identifikasi dirinya sebagai lakilaki dan malah menganggap dirinya perempuan akibat dari perilaku meniru ibunya. Kegagalan dalam mengidentifikasi identitas gender inilah yang menjadi asal mula penyebab GID (Hamdi, 2015:28). Selain itu, perilaku pembiaran perilaku cross-dress pada tokoh Yuuta oleh ibunya juga semakin memperparah GID pada tokoh Yuuta, ia menjadi kecanduan saat memakai pakaian perempuan. Ibu Yuuta membiarkan Yuuta melakukan cross-dress karena Yuuta kerap merengek untuk dipakaian pakaian perempuan bahkan Yuuta sempat menolak untuk pergi kesekolah jika tidak dipakaikan pakaian perempuan. Untuk

menyenangkan hati Yuuta, ibu Yuuta pun membiarkan Yuuta memakai pakaian perempuan hingga ia memasuki jenjang sekolah dasar. Menurut teori gender identity disorder menyatakan bahwa orang tua yang anaknya menunjukkan gejala GID seperti cross-dress kerap tidak mencegah perilaku anaknya tersebut karena mengganggap hal tersebut lucu atau untuk menyenangkan hati anak (Kring, 2010:398).

\subsection{Upaya Tokoh Yuuta mengatasi GID}

Dalam komik Bokura no Hentai, tokoh Yuuta melakukan beberapa upaya untuk mengatasi GID pada dirinya yakni terlihat pada usaha Yuuta untuk bisa kembali normal dengan mencoba untuk berperilaku dan berpenampilan lebih maskulin. Namun, meskipun tokoh Yuuta mencoba untuk kembali menjadi laki-laki, namun tokoh Yuuta masih tetap merasa tidak cocok dan tidak nyaman menjadi seorang laki-laki, sehingga ia pun memutuskan kembali pada kebiasaannya memakai pakaian perempuan karena hal tersebut lebih membuatnya merasa nyaman. Dalam hal ini, tokoh Yuuta masih berusaha untuk mencari identitas diri yang cocok dengannya.

Karena merasa kesulitan dalam menanganinya sendiri, tokoh Yuuta mendapat saran dari Ayumu yakni kakak Natsume untuk berkonsultasi ke dokter. Yuuta pun menyetujui saran terebut dan memutuskan untuk ke rumah sakit bersama ibunya. Setelah melakukan beberapa kali pemeriksaan dan konsultasi, dokter pun menyarankan Yuuta untuk mengubah identitas gender-nya menjadi perempuan setelah mendengar segala keluhan Yuuta yang mengatakan ia merasa sangat tidak nyaman menjadi laki-laki. Tokoh Yuuta pun menyetujui saran dari dokter tersebut, sehingga beberapa bulan kemudian tepatnya saat Yuuta memasuki tahun keduanya di SMP 
ia pun memutuskan untuk mengubah identitas gender-nya menjadi perempuan dan memutuskan kembali mendaftarkan diri sebagai siswi perempuan di sekolahnya, seperti data berikut.

（5）裕太の先生 : 今日から青木は女 子生徒として登校 することになりま した。何か質問あ れば先生になんで も聞いてください、 保健室の先生でも いいぞ

（ぼくらのへんたい 7, 2012:6）

Yuuta no sensei: Ima kara Aoki wa joshi seito toshite toukou suru koto ni narimashita. Minna $n$ mo kyouryoku shite morau koto mo aru kamoshirenai, nani $\mathrm{ka}$ shitsumon areba sensei ni nande mo kite kudasai, hoken shitsu no sensei demo ii zo...

(Bokura o Hentai 7, 2012:6)

Terjemahan:

Guru Yuuta : Mulai sekarang Aoki datang ke sekolah sebagai siswa perempuan. Jika kau ada pertanyaan silakan tanya padaku atau guru yang lain, kepada guru kesehatan pun juga boleh...

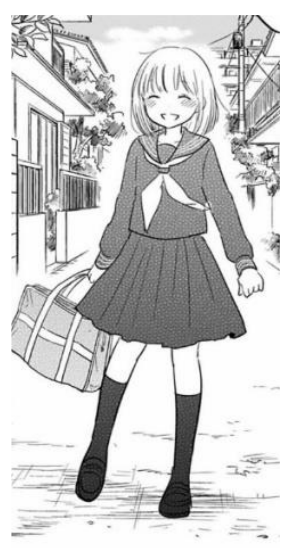

\section{Gambar 3. Ekspresi senang tokoh Yuuta setelah memutuskan menjadi perempuan \\ (Bokura no Hentai 6, 2012:150)}

Data (5) menunjukkan situasi saat seorang guru yang merupakan wali kelas Yuuta memperkenalkan kembali Yuuta sebagai siswi perempuan. Tokoh Yuuta merasa begitu bahagia ketika ia menjadi perempuan, ia merasa terlahir kembali menjadi sosok dirinya yang sesungguhnya. Meskipun beberapa teman kelasnya terutama siswa laki-laki masih belum menerima perubahan Yuuta menjadi perempuan, namun hal tersebut tidak menyurutkan Yuuta untuk menjalani kehidupannya yang baru sebagai perempuan. Selain mengubah identitas gender-nya menjadi perempuan, Yuuta juga mengubah namanya yang semula bernama Yuuta Aoki menjadi Marika Aoki.

Gambar (3) merupakan gambaran penampilan Yuuta setelah mengubah identitas gender-nya menjadi perempuan. Dalam hal ini dapat diketahui jika metode penyembuhan GID pada anak laki-laki tidak hanya berfokus pada terapi agar pasien dapat kembali hidup sebagai laki-laki normal, namun ada terapi lain yakni adalah menganjurkan pasien untuk mengubah identitas gendernya menjadi perempuan seperti yang selama ini mereka yakini. Karena inti dari penyembuhan GID adalah untuk meng- 
hilangkan kebingungan gender yang mereka alami dengan menganjurkan pasien GID untuk memilih salah satu gender, baik tetap menjadi laki-laki atau memilih untuk mengubah gender menjadi perempuan.

Schmidt, dkk dalam teori Gender Identity Disorder menyatakan bahwa penangangan untuk mengatasi GID juga dapat dilakukan dengan cara lain selain mengubah identitas gender, seperti menyarankan penderita GID untuk melakukan perubahan bentuk tubuh dengan menyuntikan hormon estrogen yang biasanya dimiliki perempuan, atau dengan melakukan operasi perubahan kelamin (First, dkk, 1994:535-536). Hal tersebut dilakukan agar penderita dapat mengatasi kebingungan gender yang selama ini mereka alami akibat GID, sehingga individu tersebut dapat memutuskan gender yang akan menjadi pilihannya. Karena ketika pasien GID sudah dapat menentukan gender yang cocok untuk mereka maka pasien sudah dapat dinyatakan sembuh dari GID.

\section{(6) Simpulan}

Berdasarkan hasil penelitian, tokoh Yuuta Aoki merupakan seorang anak laki-laki.Akan tetapi, ia memiliki keinginan untuk menjadi perempuan sejak berumur 4 tahun akibat GID yang dideritanya. Karakteristik GID pada tokoh Yuuta dibagi berdasarkan tiga dimensi yaitu 1). Dimensi fisiologis antara lain: memakai pakaian perempuan dan berdandan memakai kosmetik perempuan; 2). Dimensi psikologis antara lain: menyatakan diri perempuan, menyukai laki-laki, tidak merasa nyaman memiliki tubuh laki-laki, berkhayal menjadi perempuan, dan bertingkah laku seperti perempuan; 3) Dimensi sosiologis antara lain: sering mendapatkan ejekan dari teman-temannya dan lebih banyak meng-habiskan waktu dengan temanteman perempuannya.

Faktor penyebab terbentuknya GID pada Yuuta disebabkan oleh adanya perilaku meniru dan ibu Yuuta yang kerap membiarkan Yuuta memakai pakaian perempuan. Upaya tokoh Yuuta mengatasi GID, yaitu pertama, tokoh Yuuta berupaya untuk mencari identitas diri yang cocok dengannya, yang mana Yuuta sempat kembali berperilaku sebagai laki-laki dengan berhenti memakai pakaian perempuan dan memotong pendek rambutnya, akan tetapi tokoh Yuuta merasa tidak nyaman menjadi laki-laki, sehingga pada upaya kedua, tokoh Yuuta berupaya untuk berkonsultasi dengan dokter. Hasil dari konsultasi tersebut dokter menganjurkan tokoh Yuuta untuk mengubah identitas gender-nya dari laki-laki menjadi menjadi perempuan dan tokoh Yuuta pun menyetujuinya. Oleh karena itu, ketika tokoh Yuuta menginjak tahun kedua SMP tokoh Yuuta memulai kembali kehidupannya yang baru sebagai seorang siswi perempuan dan mengganti namanya yang semula bernama Yuuta Aoki menjadi Maria Aoki.

\section{(7) Daftar Pustaka}

Asih, Ni Kadek Sumerti. 2016. "Transgender dalam Film Animasi Tokyo Godfather Karya Satoshi Kon" (Skripsi). Denpasar: Universitas Udayana.

Danesi, Marcel. 2011. Pesan, Tanda, dan Makna: Buku Teks Dasar Mengenai Semiotika dan Teori Komunikasi. Yogyakarta: Jalasutra.

First, dkk. 1994. Diagnostic and Statistical Manual of Mental Disorder Fourth Edition. Washingon DC: American Psychiatric Association. 
Freud, Sigmund. 2016. Psikoanalisis Sigmund Freud. Jakarta: PT Gramedia Pustaka Utama.

Hamdi, Muhamad. 2015. Teori Kepribadian. Bandung: Alfabeta Bandung.

Kring, dkk. 2010. Abnormal Psychology Eleventh Edition. Amerika: Jhon Wiley \& Sons Inc.

Ratna, Nyoman Kutha. 2011. Teori, Metode,dan Teknik Penulisan Sastra. Yogyakarta: PustakaPelajar.

Wellek, Rene dan Austin Warren. 2016. Teori Kesusastraan. Diterjemahkan oleh Melani Budianta. Jakarta: PT Gramedia Pustaka Utama. 